\title{
Hour Times Picogram Per Milliliter Per Milligram Per Kilogram
}

National Cancer Institute

\section{Source}

National Cancer Institute. Hour Times Picogram Per Milliliter Per Milligram Per Kilogram.

NCI Thesaurus. Code C105471.

A dose calculation unit expressed in hours times picograms per milliliter, divided by

milligram per kilogram. 